\title{
A typology of urban speciality shops selling rural provenance food products - a contribution from Portugal
}

\author{
Alexandre Silva \\ Instituto de Ciências Sociais, Universidade de Lisboa, Lisboa, Portugal \\ Elisabete Figueiredo \\ GOVCOPP, Department of Social, Political and Territorial Sciences, \\ University of Aveiro, Aveiro, Portugal \\ Mónica Truninger \\ Instituto de Ciências Sociais, Universidade de Lisboa, Lisboa, Portugal \\ Celeste Eusébio \\ GOVCOPP, Department of Economics, Management, \\ Industrial Engineering and Tourism, University of Aveiro, Aveiro, Portugal, and \\ Teresa Forte \\ Department of Social, Political and Territorial Sciences, University of Aveiro, \\ Aveiro, Portugal
}

\begin{abstract}
Purpose - The purpose of this paper is to explore and typify the characteristics and diverse features of urban speciality stores selling rural provenance food, taking the case of three cities in Portugal.

Design/methodology/approach - The study was based on hierarchical cluster analysis, performed upon data collected from a survey to 113 shops, located in Aveiro $(n=15)$, Lisbon $(n=56)$ and Porto $(n=42)$.

Findings - The study identified three clusters of shops according to the type of rural provenance products sold, services provided and clientele characteristics: the wine focused, the rural provenance focused and the generalist. The study confirms that in Portugal, small food retail outlets, with different rural provenance patterns and degrees of specialization have considerably grown in large cities over the last decade.

Research limitations/implications - The study contributes to typifying urban speciality food stores selling rural provenance products and to addressing critical research gaps on this topic. The study highlights the dynamism of small food retail outlets and their significance, mediating and responding to changing patterns of food consumption in urban spaces.

Originality/value - This study contributes to a better understanding and characterization of food speciality shops in urban settings and their links with rural territories of provenance, an under-researched topic on the food retail literature.
\end{abstract}

Keywords Cluster analysis, Rural provenance food products, Speciality food shops,

Speciality shops' characteristics, Speciality shops' typology

Paper type Research paper

The authors would like to express their gratitude to the financial support to FCT/MCTES through national funds, and the cofunding by the FEDER, within the PT2020 Partnership Agreement and Compete 2020, for the research project STRINGS - Selling The Rural IN (urban) Gourmet Stores establishing new liaisons between town and country through the sale and consumption of rural products (PTDC/GES-OUT/29281/2017/ POCI-01-0145-FEDER-029281). https://www.stringsproject.pt/. The authors are also grateful to Carlos Ribeiro, to the production of the maps included in the article.

Typology of urban speciality shops

Received 19 November 2020 Revised 9 December 2020 25 February 2021 Accepted 20 March 2021 


\section{Introduction}

The role and significance of small food stores have changed dramatically over time, especially in the urban centres of many European countries (Guptill and Wilkins, 2002). These changes can be understood as consequences of urban recomposition dynamics, local socio-demographic transformations, as well as alterations in food consumption patterns and global supply chains (Bianchi, 2017; Truninger, 2014; Renting et al., 2003). While changes in food retail have often been subject to academic inquiry, focusing either on large retailers and long supply chains or alternative food networks (AFNs) and short food supply chains (SFSCs) (González-Azcárate et al., 2021; Watts et al., 2018; Wilson and Whitehead, 2012), research on small food shops is comparatively scarce. This gap seems more relevant when these shops have been able to persevere in spite of the hegemony of more standardized formats, and even take advantage of smaller scales by forging closer connections with customers and producers (Kneafsey et al., 2017; Seguí, 2011, Vignali et al., 2003).

By fostering new connections between various actors (retailers, distributors, producers and consumers) or reactivating and repurposing already existing ones, small shop owners in urban centres' work as modulating nodes in a web of symbolic and material links between geographies of provenance and of consumption (Singer, 2018; Seguí, 2011). As such, these shops may contribute to agriculture and rural tourism development, especially in countries like Portugal, where rural areas and agricultural activities have been declining since the 1960s (Figueiredo, 2021). Having suffered a serious aggravation of its population's economic and social conditions following the 2008 financial crisis, Portugal is a compelling example of significant transformations in small food retail patterns in urban centres, but also of how the bourgeoning of rural provenance foods sold in speciality shops may foster opportunities that benefit rural populations (Acampora and Fonte, 2008; Dogan and Gokovali, 2012; Gyimóthy, 2017). While the increasing visibility of speciality shops is suggested by circumstantial evidence in the Portuguese media (Cristino, 2018) there is, to the best of our knowledge, no systematic attempts to analyse both these shops and their links to rural areas, in Portugal and elsewhere.

This paper intends to fill this gap in existing research by addressing the following question: How are small urban stores selling rural provenance foods characterized (and differentiated) according to their products and services, and according to the connections with rural food producers and customers? To answer this question, a cluster analysis based on a survey questionnaire applied to speciality shops selling rural provenance food products in three Portuguese cities (Aveiro, Lisbon and Porto) was performed. By providing insights on key food speciality shop features, the proposed typology can be used as an analytical tool contributing to a better understanding of this type of retail in other settings.

\section{Literature review}

Previous research focusing on food products of rural provenance has underlined a global shift away from quantity and massification to the increasing preference for quality and differentiation of food products, coherent with what Goodman (2003) coined the "quality turn". Consumers report a wide range of concerns when justifying their preferences for rural provenance foods, such as environmental soundness (Bianchi, 2017; González-Azcárate et al., 2021), health and safety (Wilson and Whitehead, 2012; González-Azcárate et al., 2021), nostalgia (Truninger, 2014) authenticity or heritage and artisanship (Figueiredo, 2021). Through labels such as local, authentic, gourmet, environmentally friendly, producers developed different strategies for food quality differentiation and market segmentation responding to a growth of interest in speciality food by consumers (Vignali et al., 2003; González-Azcárate et al., 2021). As addressed by the extensive literature focusing on consumer preferences, there is an important segment of shoppers that prefer to buy food products according to qualities such as rural, local, traditional, terroir or speciality (Aprile 
et al., 2012; Balogh et al., 2015; Calvo-Porral and Lévy-Mangin, 2018; Fernandes et al., 2017; González-Azcárate et al., 2021; Watts et al., 2018).

These valuation of food qualities led to the promotion of origin labels and brandings such as Protected Geographical Indication (PGI) or Protected Designation of Origin (PDO) underpinned by European Union regulations (Fonte, 2008; González-Azcárate et al., 2021; Figueiredo, 2021). While findings are mixed, these types of labels can often meet with a growing (yet diverse) demand that is willing to pay for higher prices (Aprile et al., 2012; Balogh et al., 2015, Calvo-Porral and Lévy-Mangin, 2018; Fernandes et al., 2017). Plus, those links also promote the development of closer trust-based relations between producers and consumers through nonconventional arrangements such as consumer co-operatives, farmers' markets and direct sale activities (Watts et al., 2018). Research on AFN and SFSC (González-Azcárate et al., 2021; Renting et al., 2003; Watts, et al., 2018) has consistently analysed the role of nonconventional arrangements in the promotion of rural foodstuffs amongst urban consumers who support these initiatives based on ethical and environmental concerns (González-Azcárate et al., 2021), while also associating closer producer-consumer links with higher quality produce. These are especially valued under conditions of diminishing returns for many farmers (Renting et al., 2003; Figueiredo, 2021) and increasing concentration of power in supply chains, particularly by large retailers (Vignali et al., 2001). The role of these nonconventional supply chains in bringing urban consumers closer to rural provenance foods has often been a key topic in this research field (González-Azcárate et al., 2021; Watts et al., 2018).

There is much less knowledge about how small urban retail outlets, such as speciality and gourmet shops, may contribute to promoting rural provenance foods (Figueiredo, 2021). Additionally, while research has been showing that large retailers have sought to respond to the growing demand for provenance foods (Kneasfsey et al., 2017) much less is known about smaller formats in urban settings. However, small shops in urban centres seem to be particularly well positioned to form beneficial relations both with small-scale producers and with an urban and cosmopolitan clientele, as suggested by a few studies (Acampora and Fonte, 2008; Dogan and Gokovali, 2012, Gyimóthy, 2017). For example, Baritaux et al. (2011) point out that managers of smaller formats have a better understanding of their public's preferences and Printezis and Grebitus (2018) advocate that consumers may be willing to pay higher prices for rural products from independently owned smaller shops than from large retailers or farms, especially when shops source directly from producers (Watts et al., 2018). Furthermore, as argued by Seguí (2011), small shops are also better suited than large retailers in offering more personalised interactions with customers and conveying more detailed information about products and producers. By selling products that bear strong connections to specific territories (Figueiredo, 2021; Singer, 2018), these shops are also important in shaping perceptions about specific regions and the countryside in general. In this vein, they may contribute to fostering the economic viability of change in agricultural practices and food processing that seeks to respond to current consumers' preferences. Following other trends in Portuguese shopping in general pointed out by Cachinho (2014) food shopping has been increasingly described as an experience. Rezende and Silva (2014) have highlighted that food providers may develop different types of service encounters seeking to meet different expectations regarding the food experience. Likewise, speciality shops may be expected to provide different sets of services and sell additional types of products besides foods that can be related to the overall strategy of customer engagements.

Over the years, small shops in urban centres have lost centrality and experienced decline in several European cities due to competition from supermarkets, shopping malls and the proliferation of out-of-town large retail formats. Some of these places, such as Lisbon and Porto city centres, have experienced "recovering (regeneration) partly associated with increasing tourism, new lifestyles and gentrification” (Kärrholm et al., 2017, p. 160), that seem to have opened new market possibilities for small food shops. In effect, tourist activity in
Typology of urban speciality shops 
Portugal has risen sharply over the last years, as evidenced in the change from 12,927.907 to $27,142.416$ overnight stays in the country from 2009 to 2019. This increase was far more expressive in the country's capital - Lisbon - followed by Porto, the two cities accounting for $70 \%$ of the total of tourists in 2019 (Pordata, 2020). The number of foreign residents in the country has also changed from 436.020 in 2008 to 588.976 in 2019 (Pordata, 2020a). As Guimarães (2018) and Baptista et al. (2018) conclude in their studies focusing on the Portuguese capital, both the rise in tourist influx and the increase of foreign residents are not only pushing up the numbers in transportation and accommodation but also changing market demand for food retail in the most sought-after areas. Despite their suggestion that small retail outlets are experiencing a resurgence and increase in recent times, knowledge about the characteristics and role of small food shops in Portuguese cities is still limited.

\section{Methodology}

Data collection

This paper seeks to address the gap in existing research by providing answers to the following question: How are small urban stores selling rural provenance foods characterized (and differentiated) according to their products and services, and according to the connections with rural food producers and customers? The analysis is based on data collected through a questionnaire applied to a set of speciality food shops located in three Portuguese cities - Aveiro, Lisbon and Porto. The cities were selected on the basis of their number of residents and visitors. Lisbon and Porto are the largest cities in the country and ranked 63rd and 96th in the most visited cities in world in 2019 (Euromonitor International, 2019). Aveiro is a medium-sized city, according to Portuguese standards, and was analysed mostly for comparison with the other two, although it experienced an increase in tourism influx, it remains largely a city visited by one-day tourists. Similar to the other two cities, Aveiro experienced an increase in the number of speciality food stores in recent years.

The procedures to identify the universe of these shops in the three cities were part of a larger project [1] that started by defining what shops would encompass "urban specialty shops selling Portuguese rural provenance food products". A series of selection criteria steps were made. Firstly, we included shops that sell rural provenance foodstuffs from Portugal, independently of selling (food or non-food) products from other origins. Secondly, for the reasons highlighted in the previous section regarding the small-scale format, we decided to focus on shops with less than 10 employees. Finally, since the project also addresses the role these shops may play in promoting Portuguese rural provenance foodstuffs, stores that did not sell products of rural origin were not considered for the analysis.

Identifying small shops selling rural provenance food products was a major challenge, since no comprehensive official database is available. To overcome this difficulty, a combination of three procedures was used:

(1) Firstly, a Google Maps search was conducted based on a list of key-terms, such as regional, gourmet and speciality food shops;

(2) Secondly, a set of lists of speciality shops was compiled from leisure-related newspapers and magazines' articles, as well as leisure websites;

(3) A third list of stores was collected from a commercial database of Portuguese companies.

These three lists were finally combined in a single list containing all the shops that met the aforementioned criteria ( $N=194$, from which 23 in Aveiro, 101 in Lisbon and 70 in Porto). All the 194 shops were contacted and visited by research team members, between June and September 2019, in order to collect information. 
Questionnaire design followed a selection of variables stemming from a literature review focusing on the valorisation of rural provenance food products and, to a lesser extent, on the role of small urban shops for agriculture and rural territories (e.g. Acampora and Fonte, 2008; Figueiredo, 2021; Fonte, 2008; Kneafsey et al., 2017; Seguí, 2011; Vignali et al., 2003). The questionnaire was organised in three main parts. The first part was devoted to shops' general characterization. The second part included questions on the types of products sold, regions of origin and certification labels, services offered and forms of food products' acquisition. The third part was devoted to clientele characterization, including questions on the average number of customers, their nationality, age and gender. Apart from the open-ended questions related to the identification of the products sold and their regions of provenance, the questionnaire was mainly composed by close-ended questions. The open-ended questions were subsequently recoded into quantitative variables. Respondents were shop owners, shop managers and, in a few cases, employees appointed by the owners/managers according to their availability and knowledge about shop sales. The global survey response rate reached 61.9\% (119 out of 194 shops) and from this batch, 113 questionnaires were considered valid for the analysis.

\section{Data analysis}

Data analysis was conducted using SPSS software (Statistical Package for Social Sciences, version 25). In order to segment the shops, the answers to the open-ended question "What are the most sold rural provenance Portuguese food products?" were recoded into seven binary variables: "Vegetables and by-products", "Olive oil", "Honey, Jams and Preserves", "Cheese and other dairy products", "Wine and other Beverages", "Meat", "Cured Meat and other Animal by-products". These seven binary variables were then used as input variables in a hierarchical cluster analysis. Ward's method and the Squared Euclidean distance were used to identify homogenous groups of shops.

The agglomeration schedules and dendrogram obtained suggested the existence of two, three or four clusters. Further, in order to identify the best cluster solution, as suggested by Hair et al. (1998), the clusters of the three solutions were profiled regarding the seven variables used as input in the cluster analysis - most sold rural provenance Portuguese food products and a three-cluster solution was retained. Chi-square tests were used to identify statistically significant differences amongst the clusters regarding the following variables: (1) general characteristics of the shops; (2) type of products sold and regions of provenance; (3) certified products and mode of sourcing; (4) other services offered and (5) customers' characteristics.

\section{Findings}

Three clusters of shops were identified from the hierarchical cluster analysis based on the type of rural provenance food products sold (Table 1). Statistically significant differences amongst the clusters regarding the variables used to characterize the shops are displayed in Table 2 , the type of products sold and regions of provenance is shown in Table 3 and the certified products and mode of sourcing in Table 4. Other services provided by the shops are displayed in Table 5 and the clientele profiles in Table 6. Figure 1 displays the shops' location, by city and cluster. Considering the characteristics of each cluster and the differences between them, it is possible to further explore what are the distinctive features of each group in order to address the main research question and corresponding dimensions.

\section{Cluster profiles}

The wine-focused shops. The first and smaller cluster (11.5\%) contains 13 stores from Lisbon and Porto that sell almost exclusively wine and, to a lesser extent, other beverages and food products of rural provenance. Compared with the other two clusters, especially with the "Rural

\section{Typology of urban speciality shops}


$\mathrm{BFJ}$

\begin{tabular}{|c|c|c|c|c|c|c|c|}
\hline $\begin{array}{l}\text { Types of } \\
\text { Portuguese } \\
\text { rural products } \\
\text { sold by shops** }\end{array}$ & $N$ & tal & $\begin{array}{c}\text { "The wine } \\
\text { focused" } \\
(N=13,11.5 \%)\end{array}$ & $\begin{array}{c}\text { Clusters* } \\
\text { "The rural } \\
\text { provenance } \\
\text { focused" } \\
(N=49,43.4 \%) \\
\end{array}$ & $\begin{array}{l}\text { "The generalist" } \\
(N=51,45.1 \%)\end{array}$ & Value & are test \\
\hline $\begin{array}{l}\text { Vegetables and } \\
\text { by-products }\end{array}$ & 47 & 41.6 & 0.0 & 8.2 & 84.3 & 70.113 & 0.000 \\
\hline Olive oil & 18 & 15.9 & 0.0 & 8.2 & 27.5 & 9.725 & 0.008 \\
\hline $\begin{array}{l}\text { Honey, jams } \\
\text { and preserves }\end{array}$ & 24 & 21.2 & 0.0 & 24.5 & 23.5 & 3.975 & 0.137 \\
\hline $\begin{array}{l}\text { Cheese and } \\
\text { other dairy } \\
\text { products }\end{array}$ & 49 & 43.4 & 0.0 & 77.6 & 21.6 & 43.137 & 0.000 \\
\hline $\begin{array}{l}\text { Wine and other } \\
\text { beverages }\end{array}$ & 48 & 42.5 & 100.0 & 40.8 & 29.4 & 21.223 & 0.000 \\
\hline Meat & 13 & 11.5 & 0.0 & 26.5 & 0.0 & 19.187 & 0.000 \\
\hline $\begin{array}{l}\text { Cured meat and } \\
\text { other animal by- } \\
\text { products }\end{array}$ & 24 & 21.2 & 0.0 & 36.7 & 11.8 & 13.276 & 0.000 \\
\hline $\begin{array}{l}\text { Note(s): Values } \\
* \text { Percentage in co } \\
\text { **Only the value }\end{array}$ & & corr & $\begin{array}{l}\text { ond to the high } \\
\text { to "yes" are pr }\end{array}$ & $\begin{array}{l}\text { lues when sta } \\
\text { ed }\end{array}$ & ly significan & erences & \\
\hline
\end{tabular}

Provenance Focused", these stores are more likely to sell products from multiple regions of the country (particularly North, Centre and Alentejo and Lezíria), indicating that they are inclined to invest in a more diversified offer (including the shops located in widely known wine regions, such as Porto). The diversity on the offer is equally related to the variety of Portuguese wine regions with designation of origin, which matches the higher number of officially certified products sold by the wine-focused shops. Besides wine, olive oil and cheese sold by some of these shops, equally have certification of origin. These products are very often bought from the same wine farms and producers and are used as a complement in wine tasting events promoted by the stores. Despite no statistically significance being observed, the wine-focused shops are more likely to acquire wine and food products both directly from the producer and from a distributor. The shops included in this cluster were more often founded between the years 2000 and 2014 and they are more likely part of a chain. Besides wine and beer tastings, the wine focused shops tend to organize more workshops and cooking courses than the other two groups of stores, as well as - although with less significance - shopping delivery. In contrast with the other two clusters, people from overseas, men and individuals between their thirties and fifties are the most dominant customer profile of these shops.

The rural provenance-focused shops. The second cluster (43.9\%) contains 49 stores that focused on rural provenance food products in a more clear-cut manner than the shops included in the other two clusters. This cluster has the larger proportion of stores selling cheese (and other dairy products) together with meat and cured meat (as sausages and other animal by-products). A specific feature of this cluster is that it contains significantly more shops selling food products from a single region than the other two groups. Not surprisingly given the relevance of cheese within the products sold, the centre region is the most referred region due to its well-renowned Serra da Estrela cheese (a PDO-certified cheese) followed by the North region. Shops within this cluster sell certified products (PGI, PDO), mainly cheese and cured meat products which is a distinctive feature. Similar to the first cluster there is a tendency, although to a smaller degree, to acquire food products both directly from the producer and the distributors. However, an important part of the rural provenance-focused 


\begin{tabular}{|c|c|c|c|c|c|c|c|c|}
\hline $\begin{array}{l}\text { General stores } \\
\text { characteristics }\end{array}$ & $N$ & otal & $\begin{array}{c}\text { "The wine } \\
\text { focused" } \\
(N=13,11.5 \%)\end{array}$ & $\begin{array}{l}\text { Clusters* } \\
\text { "The rural } \\
\text { provenance } \\
\text { focused" } \\
(N=49,43.4 \%)\end{array}$ & $\begin{array}{l}\text { "The generalist" } \\
(N=51,45.1 \%)\end{array}$ & Chi-squ & $p$-value & $\begin{array}{r}\text { Typology of } \\
\text { urban } \\
\text { speciality } \\
\text { shops }\end{array}$ \\
\hline \multicolumn{9}{|l|}{ City } \\
\hline Porto & 42 & 37.2 & 46.2 & 40.8 & 31.4 & \multirow[t]{3}{*}{ a) } & \multirow[t]{3}{*}{ a) } & \\
\hline Aveiro & 15 & 13.3 & 0.0 & 16.3 & 13.7 & & & \\
\hline Lisbon & 56 & 49.6 & 53.8 & 42.9 & 54.9 & & & \\
\hline \multicolumn{9}{|l|}{ Company type } \\
\hline $\begin{array}{l}\text { Single member } \\
\text { company }\end{array}$ & 55 & 53.9 & 58.3 & 61.9 & 45.8 & \multirow[t]{2}{*}{2.435} & \multirow[t]{2}{*}{0.296} & \\
\hline $\begin{array}{l}\text { Collective } \\
\text { company }\end{array}$ & 47 & 46.1 & 41.7 & 38.1 & 54.2 & & & \\
\hline $\begin{array}{l}\text { Part of family } \\
\text { company** }\end{array}$ & 79 & 71.8 & 69.2 & 76.6 & 68.0 & 0.933 & 0.627 & \\
\hline $\begin{array}{l}\text { Integrates } \\
\text { chain/ } \\
\text { franchising** }\end{array}$ & 10 & 8.8 & 15.4 & 8.2 & 7.8 & a) & a) & \\
\hline \multicolumn{9}{|l|}{ Year of founding } \\
\hline Before 2000 & 32 & 28.6 & 30.8 & 35.4 & 21.6 & \multirow[t]{3}{*}{ a) } & \multirow[t]{3}{*}{ a) } & \\
\hline [2001-2014] & 34 & 30.4 & 38.5 & 29.2 & 29.4 & & & \\
\hline [2015-2019] & 46 & 41.1 & 30.8 & 35.4 & 49.0 & & & \\
\hline \multicolumn{9}{|c|}{ Last management, year of start } \\
\hline Before 2000 & 23 & 21.3 & 23.1 & 33.3 & 10.0 & \multirow[t]{3}{*}{ a) } & \multirow[t]{3}{*}{ a) } & \\
\hline [2001-2014] & 33 & 30.6 & 30.8 & 28.9 & 32.0 & & & \\
\hline [2015-2019] & 52 & 48.1 & 46.2 & 37.8 & 58.0 & & & \\
\hline \multicolumn{9}{|c|}{ Number of employees } \\
\hline only 1 & 24 & 21.40 & 33.30 & 18.40 & 21.60 & \multirow[t]{3}{*}{ a) } & \multirow[t]{3}{*}{ a) } & \\
\hline [2-9] & 81 & 72.30 & 66.70 & 73.50 & 72.50 & & & \\
\hline [10-15] & 7 & 6.30 & 0.00 & 8.20 & 5.90 & & & \\
\hline \multicolumn{8}{|c|}{$\begin{array}{l}\text { Note(s): Values in italic correspond to the highest values when statistically significant differences exist } \\
\text { *Percentage in column } \\
\text { **Only the values corresponding to "yes" are presented } \\
\text { a) The assumptions of chi-square test were not observed }\end{array}$} & $\begin{array}{r}\text { Table } 2 . \\
\text { Cluster profile } \\
\text { regarding the general } \\
\text { stores characteristics }\end{array}$ \\
\hline
\end{tabular}

shops buys directly from the producer, particularly cheese that is, again, a distinctive feature that contrasts with the first cluster. These shops are located in all the three cities, even though its number is proportionally larger in Aveiro. Even without statistical significance, these shops are more likely part of a family company and, compared with the other clusters, a higher number of shops was founded before the year 2000, including some as far back as the 1800s (in Lisbon and Porto). The rural provenance-focused shops are more likely to offer a wider range of services, such as wine and food tastings, cafeteria, restaurant and takeaway meals. These stores are also more likely to develop their own food products' brands, exploring a different angle on the connections between (rural) food production and (urban) commercialization. Customers tend to be most likely both male and female, from all ages as well as from Portugal or Overseas.

The generalist shops. The last and larger cluster (45.1\%) includes 52 stores that, compared with the previous ones, are more likely to sell vegetables and related products as well as olive oil. These shops also tend to sell a wide variety of other products (from foodstuffs to hygiene 
$\mathrm{BFJ}$

\begin{tabular}{|c|c|c|c|c|c|c|c|}
\hline $\begin{array}{l}\text { Products sold } \\
\text { and regions of } \\
\text { provenance }\end{array}$ & $N$ & otal & $\begin{array}{c}\text { "The wine } \\
\text { focused" } \\
(N=13,11.5 \%)\end{array}$ & $\begin{array}{l}\text { Clusters* } \\
\text { "The rural } \\
\text { provenance } \\
\text { focused" } \\
(N=49,43.4 \%)\end{array}$ & $\begin{array}{l}\text { "The generalist" } \\
(N=51,45.1 \%)\end{array}$ & Chi-sq & are test \\
\hline \multicolumn{8}{|c|}{ Types of products sold*** } \\
\hline $\begin{array}{l}\text { Foods of rural } \\
\text { provenance }\end{array}$ & 103 & 91.2 & 30.8 & 98.0 & 100.0 & a) & a) \\
\hline Other foods & 77 & 68.1 & 23.1 & 69.4 & 78.4 & 14.684 & 0.001 \\
\hline Beverages & 98 & 86.7 & 100.0 & 89.8 & 80.4 & 4.168 & 0.124 \\
\hline Handicraft & 28 & 24.8 & م0 & 26.5 & 29.4 & 4.950 & 0.084 \\
\hline $\begin{array}{l}\text { Hygiene and } \\
\text { cleaning }\end{array}$ & 31 & 27.4 & 0.0 & 14.3 & 47.1 & 19.036 & 0.000 \\
\hline \multicolumn{8}{|c|}{ Diversity of provenance } \\
\hline Single regions & 19 & 17.0 & 7.7 & 31.3 & 5.9 & 12,194 & 0.002 \\
\hline $\begin{array}{l}\text { Multiple } \\
\text { regions }\end{array}$ & 93 & 83.0 & 92.3 & 68.8 & 94.1 & & \\
\hline \multicolumn{8}{|c|}{ Single region of provenance } \\
\hline $\begin{array}{l}\text { Alentejo and } \\
\text { Lezíria }\end{array}$ & 2 & 10.5 & 0.0 & 8.3 & 16.7 & a) & a) \\
\hline Centre & 5 & 26.3 & 0.0 & 41.7 & 0.0 & & \\
\hline North & 9 & 47.4 & 100.0 & & 66.7 & & \\
\hline Açores & 3 & 15.8 & 0.0 & 16.7 & 16.7 & & \\
\hline \multicolumn{8}{|c|}{ Multiple regions of provenance** } \\
\hline Açores & 8 & 9.1 & 0.0 & 12.1 & 8.9 & a) & a) \\
\hline $\begin{array}{l}\text { Alentejo and } \\
\text { Lezíria }\end{array}$ & 38 & 43.2 & 40.0 & 39.4 & 46.7 & 0.457 & 0.796 \\
\hline Algarve & 18 & 20.50 & 10.00 & 12.10 & 28.90 & 4,048 & 0.132 \\
\hline Centre & 55 & 62.50 & 70.00 & 72.70 & 53.30 & 3,326 & 0.190 \\
\hline Lisbon & 12 & 13.60 & 30.00 & 15.20 & 8.90 & a) & a) \\
\hline Madeira & 4 & 4.50 & 0.00 & 0.00 & 8.90 & a) & a) \\
\hline North & 65 & 73.90 & 90.00 & 63.60 & 77.80 & 3,494 & 0.174 \\
\hline \multicolumn{8}{|c|}{$\begin{array}{l}\text { Note(s): Values in italic correspond to the highest values when statistically significant differences exist } \\
\text { *Percentage in column } \\
\text { **Only the values corresponding to "yes" are presented } \\
\text { a) The assumptions of chi-square test were not observed }\end{array}$} \\
\hline
\end{tabular}

and cleaning products both of rural and non-rural provenances) that justifies the cluster designation. The variety of products commercialized by these shops goes together with the higher diversity of regions of origin, even though, as in the other two clusters, North, Centre, Alentejo and Lezíria are the most frequent regions of provenance. In a similar vein, but with less expression, the generalist shops sell certified food products. Amongst these, vegetables, olive oil together with honey, jams and other preserves, are the most frequent, which significantly distinguishes this group from the other two clusters. A common feature to the other two clusters lies in the acquisition of food products both from distributors and directly from producers, although the shops in this third cluster are more likely to purchase the products directly from the producers, following a similar pattern to the rural provenancefocussed cluster. Like this latter cluster, the direct purchase from producers is most evident in the case of the products that firstly define these clusters (correspondingly cheese and vegetables and olive oil). The generalist shops are set in all the three cities analysed, although they are proportionally higher in Lisbon. These shops are more likely to be recently founded 


\begin{tabular}{|c|c|c|c|c|c|c|c|c|}
\hline $\begin{array}{l}\text { Characteristics of } \\
\text { products sold }\end{array}$ & $N$ & otal & $\begin{array}{c}\text { "The wine } \\
\text { focused" } \\
(N=13,11.5 \%)\end{array}$ & $\begin{array}{l}\text { Clusters* } \\
\text { "The rural } \\
\text { provenance } \\
\text { focused" } \\
(N=49,43.4 \%) \\
\end{array}$ & $\begin{array}{l}\text { "The generalist" } \\
(N=51,45.1 \%)\end{array}$ & Value & $p$-value & $\begin{array}{r}\text { Typology of } \\
\text { urban } \\
\text { speciality } \\
\text { shops }\end{array}$ \\
\hline \multicolumn{9}{|c|}{ Number of certified products } \\
\hline None & 8 & 7.6 & 0.0 & 8.9 & 8.5 & a) & a) & \\
\hline $\begin{array}{l}\text { Up of the five } \\
\text { products }\end{array}$ & 23 & 21.9 & 7.7 & 22.2 & 25.5 & & & \\
\hline $\begin{array}{l}\text { More than five } \\
\text { products }\end{array}$ & 74 & 70.5 & 92.3 & 68.9 & 66.0 & & & \\
\hline \multicolumn{9}{|c|}{ Most sold certified product types** } \\
\hline $\begin{array}{l}\text { Vegetables and } \\
\text { related products }\end{array}$ & 27 & 29.3 & 0.0 & 18.9 & 47.6 & 14,103 & 0.010 & \\
\hline Olive oil & 25 & 27.2 & 15.4 & 13.5 & 42.9 & 9,622 & 0.008 & \\
\hline $\begin{array}{l}\text { Honey, jams and } \\
\text { preserves }\end{array}$ & 13 & 14.1 & 0.0 & 8.1 & 23.8 & 6,488 & 0.039 & \\
\hline $\begin{array}{l}\text { Cheese and other } \\
\text { dairy products }\end{array}$ & 45 & 48.9 & 7.7 & 73.0 & 40.5 & 18,608 & 0.000 & \\
\hline $\begin{array}{l}\text { Wine and other } \\
\text { beverages }\end{array}$ & 43 & 46.7 & 92.3 & 45.9 & 33.3 & 13,885 & 0.001 & \\
\hline Meat & 4 & 4.3 & 0.0 & 10.8 & 0.0 & a) & a) & \\
\hline $\begin{array}{l}\text { Cured meat and } \\
\text { other animal by- } \\
\text { products }\end{array}$ & 17 & 18.5 & 0.0 & 32.4 & 11.9 & 8,934 & 0.011 & \\
\hline \multicolumn{9}{|c|}{ Source of majority of rural products sold } \\
\hline $\begin{array}{l}\text { Directly from } \\
\text { producers }\end{array}$ & 43 & 38.7 & 15.4 & 38.8 & 44.9 & a) & a) & \\
\hline $\begin{array}{l}\text { Through } \\
\text { intermediary/ } \\
\text { distributor }\end{array}$ & 11 & 9.9 & 15.4 & 14.3 & 4.1 & & & \\
\hline $\begin{array}{l}\text { Both producer } \\
\text { and distributor }\end{array}$ & 57 & 51.4 & 69.2 & 46.9 & 51.0 & & & \\
\hline \multicolumn{9}{|c|}{ Products brought directly from the producer** } \\
\hline $\begin{array}{l}\text { Vegetables and } \\
\text { related products }\end{array}$ & 34 & 37.40 & 11.10 & 14.00 & 69.20 & 29,643 & 0.000 & \\
\hline Olive oil & 19 & 20.90 & 0.00 & 14.00 & 33.30 & 7,285 & 0.026 & \\
\hline $\begin{array}{l}\text { Honey, jams and } \\
\text { preserves }\end{array}$ & 22 & 24.20 & 11.10 & 23.30 & 28.20 & 1.203 & 0.548 & \\
\hline $\begin{array}{l}\text { Cheese and other } \\
\text { dairy products }\end{array}$ & 34 & 37.40 & 0.00 & 58.10 & 23.10 & 16,701 & 0.000 & \\
\hline $\begin{array}{l}\text { Wine and other } \\
\text { beverages }\end{array}$ & 34 & 37.40 & 100.00 & 34.90 & 25.60 & 17,491 & 0.000 & \\
\hline Meat & 8 & 8.80 & 0.00 & 8.80 & 0.00 & a) & a) & \\
\hline $\begin{array}{l}\text { Cured meat and } \\
\text { other animal by- } \\
\text { products }\end{array}$ & 16 & 17.60 & 0.00 & 25.60 & 12.80 & 4,429 & 0.109 & \\
\hline \multicolumn{8}{|c|}{$\begin{array}{l}\text { Note(s): Values in italic correspond to the highest values when statistically significant differences exist } \\
\text { *Percentage in column } \\
\text { **Only the values corresponding to "yes" are presented } \\
\text { a) The assumptions of chi-square test were not observed }\end{array}$} & $\begin{array}{r}\text { Cluster profile } \\
\text { regarding the } \\
\text { characteristics of } \\
\text { products sold }\end{array}$ \\
\hline
\end{tabular}


BFJ

\begin{tabular}{|c|c|c|c|c|c|c|c|}
\hline \multirow{2}{*}{$\begin{array}{l}\text { Other services } \\
\text { provided by the } \\
\text { shops** }\end{array}$} & \multicolumn{2}{|c|}{ Total } & \multirow{2}{*}{$\begin{array}{c}\text { "The wine } \\
\text { focused" } \\
(N=13,11.5 \%)\end{array}$} & \multirow{2}{*}{$\begin{array}{c}\text { Clusters* } \\
\text { "The rural } \\
\text { provenance } \\
\text { focused" } \\
(N=49,43.4 \%)\end{array}$} & \multirow{2}{*}{$\begin{array}{l}\text { "The generalist" } \\
(N=51,45.1 \%)\end{array}$} & \multicolumn{2}{|c|}{ Chi-square test } \\
\hline & $N$ & $\%$ & & & & Value & $p$-value \\
\hline Restaurant & 11 & 9.7 & 0.0 & 14.3 & 7.8 & a) & a) \\
\hline Cafeteria & 26 & 23.0 & 7.7 & 28.6 & 21.6 & 2,637 & 0.268 \\
\hline Meal take away & 12 & 10.6 & 7.7 & 12.2 & 9.8 & 0.285 & 0.865 \\
\hline Meal delivery & 6 & 5.3 & 0.0 & 8.2 & 3.9 & a) & \\
\hline Bookshop & 5 & 4.4 & 0.0 & 4.1 & 5.9 & a) & \\
\hline $\begin{array}{l}\text { Workshops/ } \\
\text { cooking courses }\end{array}$ & 15 & 13.3 & 23.1 & 4.1 & 19.6 & 6,459 & 0.040 \\
\hline Food tastings & 64 & 56.6 & 30.8 & 53.1 & 66.7 & 5,886 & 0.053 \\
\hline $\begin{array}{l}\text { Wine or } \\
\text { traditional beer } \\
\text { tasting }\end{array}$ & 65 & 57.5 & 84.6 & 57.1 & 51.0 & 4,802 & 0.091 \\
\hline Event catering & 10 & 8.8 & 7.7 & 6.1 & 11.8 & a) & \\
\hline $\begin{array}{l}\text { Food gift } \\
\text { baskets }\end{array}$ & 41 & 39.8 & 30.8 & 36.7 & 45.1 & 1,232 & 0.540 \\
\hline Gift card & 12 & 10.6 & 7.7 & 12.2 & 9.8 & 0.289 & 0.865 \\
\hline $\begin{array}{l}\text { Own brand of } \\
\text { products }\end{array}$ & 23 & 20.4 & 7.7 & 22.4 & 21.6 & 1,465 & 0.481 \\
\hline $\begin{array}{l}\text { Online } \\
\text { shopping }\end{array}$ & 30 & 26.5 & 30.8 & 22.4 & 29.4 & 0.755 & 0.685 \\
\hline App for sales & 4 & 3.5 & 0.0 & 6.1 & 2.0 & a) & \\
\hline $\begin{array}{l}\text { Shopping } \\
\text { delivery }\end{array}$ & 32 & 28.3 & 46.2 & 24.5 & 27.5 & 2,410 & 0.300 \\
\hline $\begin{array}{l}\text { Mail shopping } \\
\text { delivery }\end{array}$ & 38 & 33.6 & 46.2 & 24.5 & 39.2 & 3,461 & 0.177 \\
\hline $\begin{array}{l}\text { Restaurant } \\
\text { supplying }\end{array}$ & 28 & 24.8 & 7.7 & 24.5 & 29.4 & 2,626 & 0.269 \\
\hline $\begin{array}{l}\text { Note(s): Values } \\
\text { *Percentage in co } \\
\text { **Only the values } \\
\text { a) The assumptio }\end{array}$ & $\begin{array}{l}\text { in ita } \\
\text { lumn } \\
\text { corr }\end{array}$ & $\begin{array}{l}\text { corre } \\
\text { pond } \\
\text { i-squ }\end{array}$ & $\begin{array}{l}\text { ond to the highe } \\
\text { to "yes" are pre } \\
\text { test were not o }\end{array}$ & $\begin{array}{l}\text { values when stat } \\
\text { ted } \\
\text { rved }\end{array}$ & cally significant di & ferences & \\
\hline
\end{tabular}

(after the year of 2010), possibly reflecting the urban tourism investment as a recovery strategy from the financial crisis. They also tend to be owned by a collective company, although some possess a family nature, similar to the second cluster. As in the case of the shops from the second cluster, the generalist are more likely to organize food tasting events. Besides that, although without statistical significance, they seem more likely to offer event catering and gift baskets. As to the customer profile this cluster is characterized by the predominance of women, Portuguese born and from all ages.

\section{Discussion}

The purpose of this study was to explore the characteristics and diverse features of urban speciality food stores selling rural provenance food, taking the cases of three cities in Portugal. Small food retail, particularly speciality food shops, has received much less attention than large retailers and their impacts on urban consumption landscapes. Therefore, through a hierarchical cluster analysis, this study aimed at contributing to typify urban speciality food stores and addressing critical gaps regarding both rural provenance food production and commercialization research. The features of the shops found show that small retail is a dynamic sector and that its significant role as mediating and responding to 


\begin{tabular}{|c|c|c|c|c|c|c|c|c|}
\hline $\begin{array}{l}\text { Customers' } \\
\text { characteristics }\end{array}$ & $N$ & tal & $\begin{array}{c}\text { "The wine } \\
\text { focused" } \\
(N=13,11.5 \%)\end{array}$ & $\begin{array}{c}\text { Clusters* } \\
\text { "The rural } \\
\text { provenance } \\
\text { focused" } \\
(N=49,43.4 \%)\end{array}$ & $\begin{array}{l}\text { "The generalist" } \\
(N=51,45.1 \%)\end{array}$ & Chi-squ & are test & $\begin{array}{r}\text { Typology of } \\
\text { urban } \\
\text { speciality } \\
\text { shops }\end{array}$ \\
\hline \multicolumn{9}{|c|}{ Nationality (majority of customers) } \\
\hline Portuguese & 47 & 41.6 & 30.8 & 38.8 & 47.1 & \multirow[t]{3}{*}{ a) } & \multirow[t]{3}{*}{ a) } & \\
\hline Foreigners & 28 & 24.8 & 23.1 & 20.4 & 29.4 & & & \\
\hline Both & 38 & 33.6 & 46.2 & 40.8 & 23.5 & & & \\
\hline \multicolumn{9}{|c|}{ Sex (majority of customers) } \\
\hline Women & 24 & 21.6 & 0.0 & 12.5 & 36.0 & \multirow[t]{3}{*}{ a) } & \multirow[t]{3}{*}{ a) } & \\
\hline Men & 7 & 6.3 & 30.8 & 2.1 & 4.0 & & & \\
\hline Both & 80 & 72.1 & 69.2 & 85.4 & 60.0 & & & \\
\hline \multicolumn{9}{|c|}{ Age group (majority of customers) } \\
\hline $20-35$ years & 5 & 4.4 & 7.7 & 2.0 & 5.9 & \multirow[t]{6}{*}{ a) } & \multirow[t]{6}{*}{ a) } & \\
\hline $36-50$ years & 39 & 34.5 & 46.2 & 36.7 & 29.4 & & & \\
\hline $51-65$ years & 9 & 8.0 & 15.4 & 4.1 & 9.8 & & & \\
\hline More than 65 & 1 & 0.9 & 0.0 & 0.0 & 2.0 & & & Table 6. \\
\hline $\begin{array}{l}\text { years } \\
\text { All ages }\end{array}$ & 59 & 52.2 & 30.8 & 57.1 & 52.9 & & & $\begin{array}{l}\text { Cluster profile } \\
\text { regarding the }\end{array}$ \\
\hline \multicolumn{6}{|c|}{$\begin{array}{l}\text { Note(s): *Percentage in column } \\
\text { a) The assumptions of chi-square test were not observed }\end{array}$} & & & $\begin{array}{r}\text { customers' } \\
\text { characteristics }\end{array}$ \\
\hline
\end{tabular}

changing patterns of food consumption deserves more research. The growing number of these shops within Portuguese urban centres (Guimarães, 2018), following the aforementioned growth of tourist influx and the increase in foreigner residents (Baptista et al., 2018; Kärrholm et al., 2017) reinforces the need to study and typify these stores, in Portugal as elsewhere.

The research focused on three Portuguese cities that have experienced increasing tourist and visitor numbers over the last decade. In fact, overnight stays in Portugal increased more than $100 \%$ in the last 10 years. In Lisbon, the increase was $230 \%$ and in Porto $300 \%$. In Aveiro, although numbers are lower, the increase represented $200 \%$. As previously stated, Lisbon and Porto currently account for $70 \%$ of the total number of tourist's overnight stays in the country (Pordata, 2020). This increase, together with the growing numbers of foreign residents (Baptista et al., 2018; Guimarães, 2018; Kärrholm et al., 2017) contributed to changing the market demand for food retail and to a resurgence of smaller food shops. This resurgence is fully confirmed by our data, as the majority $(64.4 \%)$ of the stores surveyed were founded in the last 10 years. However, some stores that were founded in the 19th century or in the first three decades of the 20th century (especially dominant in the second and third clusters) were able to resist the increasing penetration of more standardized retail formats (Kneafsey et al., 2017; Seguí, 2011, Vignali et al., 2003). This suggests that different types of shops have different degrees of adaptability and resilience to shifts in consumer demand, especially to the changes in food tastes towards rural provenance.

One of those changes such as the greater significance of provenance in food consumption preferences (Aprile et al., 2012; Balogh et al., 2015, Calvo-Porral and LévyMangin, 2018; Fernandes et al., 2017; González-Azcárate et al., 2021; Watts et al., 2018), is reflected in the diverse ways that rural provenance is represented in the different types of shops analysed. Food shops may be linked to a particular region, a family or type of product or even try to portray the countryside as a whole, especially to overseas customers. This 
$\mathrm{BFJ}$

Figure 1.

Location of shops by city and cluster

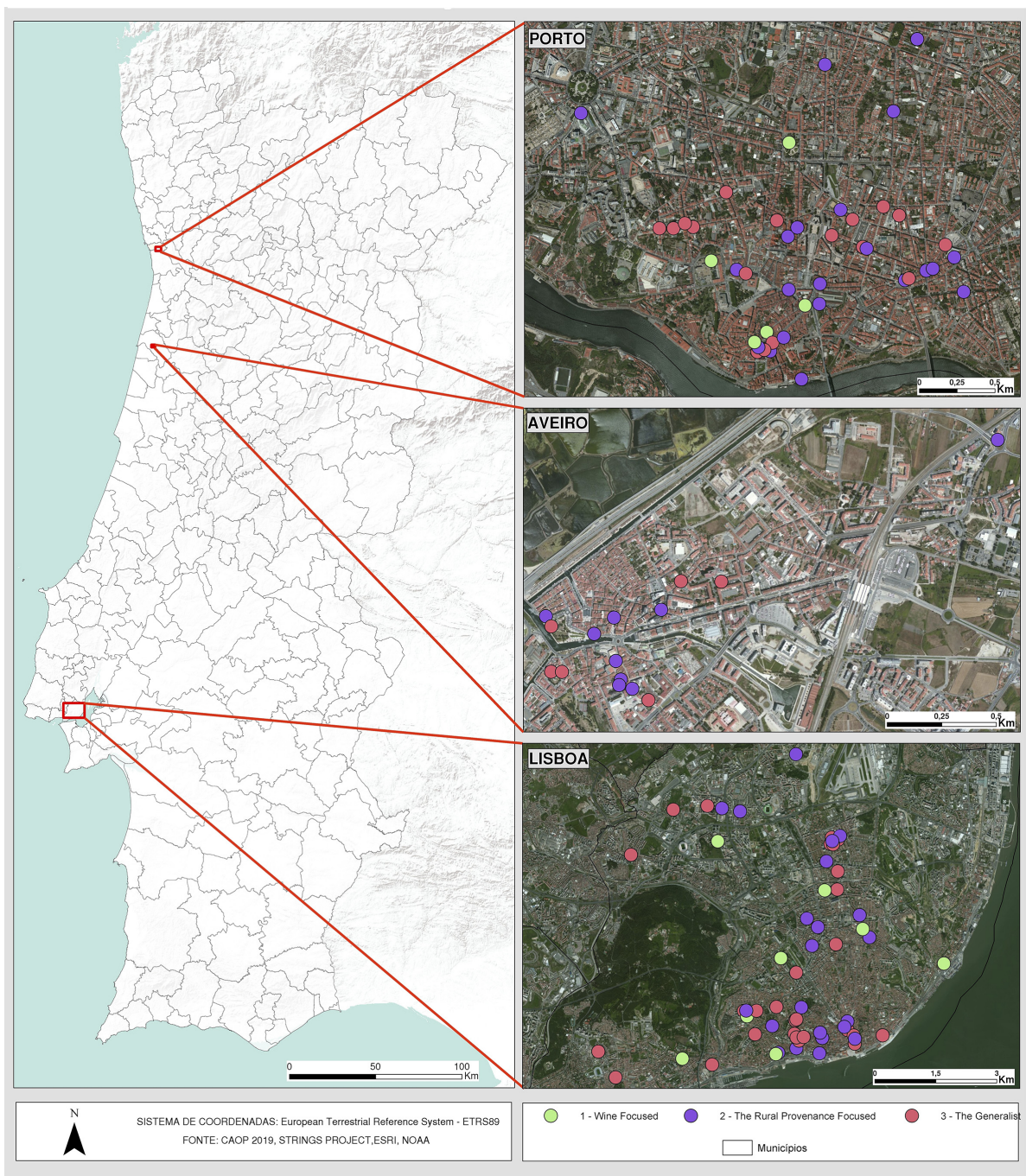

could explain the sale of other than food items that are particularly able to bear these symbolic associations, such as handicraft, especially in the second and, more evidently, in the third cluster. This broader meaning of provenance is in line with the findings of Figueiredo (2021) regarding both the use of region and nation in small shops products' promotion. Although the shops in all three clusters tend to acquire their products from diverse regions, suggesting the relevance of displaying the variety of Portuguese products, this is more visible in the wine focused and the generalist clusters. The rural provenancefocused cluster is more likely to sell products from a single region, according to the type of product. In all cases it is evident that rural provenance matters (Figueiredo, 2021), and some areas of the country are specifically targeted as commercially appealing provenances. This is particularly true regarding certified products, sold by almost all the shops included in the 
three clusters, particularly in the wine focused and in the rural provenance focused. This prominence is certainly due to the very character of the products sold by these shops, often anchored in particular regions and terroirs officially recognized and labelled with controlled origin designations (González-Azcárate et al., 2021; Figueiredo, 2021; Fonte, 2008).

The relevance of provenance when it comes to food products is also demonstrated by the direct links the shops have with producers. In fact, these direct connections form an important part of product sourcing and are more likely to be valued by the rural provenancefocused shops and the generalist stores, evincing advantages for both producers and retailers, as well as the role the former play in promoting rural provenance food amongst urban consumers (corroborating the findings of Baritaux et al., 2011; Printezis and Grebitus, 2018; Seguí, 2011 and Watts et al., 2018). This promotion is also demonstrated through the services provided by the shops, whether to improve shopping convenience through the availability of online sales or delivery services, or to improve consumer experiences by organizing food and wine tasting events or even by providing a multifunctional space that includes a cafeteria or a restaurant. This is in line with the conclusions of Cachinho (2014) on the current trend to embed food sales in richer and more rewarding consumption experiences.

The three clusters of shops present some diversity regarding clientele characteristics. While the rural provenance-focused shops are visited both by women and men, both from Portugal and overseas and from all ages, in the generalist shops there is a higher proportion of Portuguese and women amongst customers, possibly due to the wider selection of products and to the prevalent role women still play in the domestic division of labour, namely, shopping (e.g. Achón et al., 2017). On the contrary, in the highly specialized wine-focused shops, men (often from overseas), between 30 and 50 years old, are the most frequent customers, suggesting relevant differences regarding gender and age in speciality rural provenance food-related products shopping.

\section{Conclusions, limitations and future research}

The empirical evidence discussed above reveals that small food retail outlets with different rural provenance patterns and degrees of specialization flourished in Portugal in the last decade. This accompanied the enormous tourist influx (and to a lesser extent, the foreign residents' growth), which was particularly visible in the three cities analysed, especially in Lisbon and Porto. From wine speciality shops to more generalist ones, these shops seem to fill the current consumers' demands and preferences regarding food. The proposed typology of shops clearly demonstrates these matters by highlighting the diversity both between and within the different clusters, in terms of products sold, services offered and connections with rural provenance food producers. Therefore, the diverse and sometimes-overlapping features of the shops analysed seem to be related with the need to promote the variety of the country's rural provenance food-related production to a wider clientele, increasingly interested in the Portuguese provenance of the food consumed.

While we are aware that the proposed typology represents a single contribution to address a research gap regarding urban speciality food shops, our findings may provide the basis for further analyses concerning the diversity of shops and their connections to specific territories and producers. Particularly relevant is the need to extend the research to other urban settings, both in Portugal and other countries, in order to further test the adequacy and expand the scope of the proposed typology. Further evidence is still needed on the type and content of the different connections between shops and producers, together with the products sold. As these may refer to more or less organised supply chains, data on this could be particularly insightful for policy recommendations, as well as to better understand the impacts on
Typology of urban speciality shops

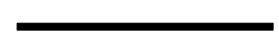


agriculture, rural development and on the strengthening of rural-urban connections. Finally, the coronavirus disease 2019 (COVID-19) pandemic situation may open new lines for research, as small shops are particularly reliant on tourism and, therefore, especially vulnerable to lockdown and border closure restrictions imposed by governments. On one hand, this may compromise their survival and imply changes in urban retail landscapes, on the other, this type of research may be insightful to inform which retail shops are more resilient to disruptive change.

\section{Note}

1. STRINGS - Selling The Rural IN (urban) Gourmet Stores - establishing new liaisons between town and country through the sale and consumption of rural products (PTDC/GES-OUT/29281/2017/ POCI01-0145.

\section{References}

Acampora, T. and Fonte, M. (2008), "Productos típicos, estrategias de desarrollo rural y conocimiento local”, Revista Opera, Vol. 7 No. Mayo, pp. 191-212.

Achón, M., Serrano, M., García-González, Á., Alonso-Aperte, E. and Varela-Moreiras, G. (2017), "Present food shopping habits in the Spanish adult population: a cross-sectional study", Nutrients, Vol. 9, p. 508.

Aprile, M.C., Caputo, V. and Nayga, R. (2012), “Consumers' valuation of food quality labels: the case of the European geographic indication and organic farming labels", International Journal of Consumer Studies, Vol. 36, pp. 158-165.

Balogh, P., Békési, D., Gorton, M., Popp, J. and Lengyel, P. (2015), "Consumer willingness to pay for traditional food products", Food Policy, Vol. 61, pp. 176-184.

Baptista, L., Nofre, J. and Jorge, M. (2018), "Mobilidade, Cidade e Turismo: pistas para analisar as transformações em curso no centro histórico de Lisboa”, Sociologia: Revista da Faculdade de Letras da Universidade do Porto, pp. 14-32, Número temático - Cidade, cultura e turismo: novos cruzamentos.

Baritaux, V., Tebby, C. and Revoredo-Giha, C. (2011), "How well do food retailers know their customers? The case of mountain food products in Europe", Journal on Chain and Network Science, Vol. 11 No. 3, pp. 223-234.

Bianchi, C. (2017), "Exploring urban consumers' attitudes and intentions to purchase local food in Chile", Journal of Food Products Marketing, Vol. 23 No. 5, pp. 553-569.

Cachinho, H. (2014), "Consumerscapes and the resilience assessment of urban retail systems", Cities, Vol. 36, pp. 131-144.

Calvo-Porral, C. and Lévy-Mangin, J. (2018), "From 'foodies' to 'cherry-pickers': a clustered-based segmentation of specialty food retail customers", Journal of Retailing and Consumer Services, Vol. 43, pp. 278-284.

Cristino, S. (2018), “Apesar do 'elevado dinamismo', estão a fechar mais lojas em Lisboa do que as que abrem”, available at: https://ocorvo.pt/apesar-do-elevado-dinamismo-estao-a-fechar-mais-lojasem-lisboa-do-que-as-que-abrem/ (accessed 9 November 2020).

Dogan, B. and Gokovali, U. (2012), "Geographical indications: the aspects of rural development and marketing through the traditional products", Procedia - Social and Behavioral Sciences, Vol. 62, pp. 761-765.

Euromonitor International (2019), "Top 100 city destination ranking”, available at: https://go. euromonitor.com/white-paper-travel-2019-100-cities.html (accessed 10 February 2021).

Fernandes, A., Ribeiro, M., Cabo, P. and Matos, A. (2017), "Perfil do consumidor e hábitos de compra e consumo de produtos gourmet em Bragança, Portugal", Revista de Ciencias Agrarias, Vol. 40, pp. 298-308. 
Figueiredo, E. (2021), "Rural Provenance Food as Cultural Heritage - a way of promoting rural attractiveness and development?", in Oliveira, L., Migueis, A. and Melro, A. (Eds), Handbook of Research on Cultural Heritage and its Impact on Territory Innovation and Development, IGI Global, Hershey, pp. 114-137.

Fonte, M. (2008), "Knowledge, Food and Place. A way of producing, a way of knowing", Sociologia Ruralis, Vol. 48 No. 3, pp. 200-222.

González-Azcárate, M., Maceín, J.L.C. and Bardají, I. (2021), "Why buying directly from producers is a valuable choice? Expanding the scope of short food supply chains in Spain", Sustainable Production and Consumption, Vol. 26, pp. 911-920.

Goodman, D. (2003), "The quality 'turn' and alternative food practices: reflections and agenda", Journal of Rural Studies, Vol. 19 No. 1, pp. 1-7.

Guimarães, P. (2018), "The transformation of retail markets in Lisbon: an analysis through the lens of retail gentrification", European Planning Studies, Vol. 26 No. 7, pp. 1450-1470.

Guptill, A. and Wilkins, J.L. (2002), "Buying into the food system: trends in food retailing in the US and implications for local foods", Agriculture and Human Values, Vol. 19, pp. 39-51.

Gyimóthy, S. (2017), "The reinvention of terroir in Danish food place promotion", European Planning Studies, Vol. 25 No. 7, pp. 1200-1216.

Hair, F., AndersonTatham, R.F.R.L. and Black, W.C. (1998), Multivariate Data Analysis, Prentice Hall, New Jersey.

Kärrholm, M., Barata-Salgueiro, T., Soumagne, J., Fernandes, J. and Chamusca, P. (2017), "Time-space complexity and the opening hours of commerce: a study of four European cities", Journal of Geography and Spatial Planning, Vol. 12, pp. 153-77.

Kneafsey, M., Venn, L. and Bos, E. (2017), "Consuming rural connections: tracing leeks back to their roots", in Miele, M., Higgins, V., Bjørkhaug, H. and Truninger, M. (Eds), Transforming the Rural: Global Processes and Local Futures, Emerald, Bingley, pp. 197-220.

Pordata (2020), "Hóspedes nos alojamentos turísticos", available at: https://www.pordata.pt/Portugal/ $\mathrm{H} \% \mathrm{c} 3 \%$ b3spedes + nos + alojamentos + tur $\% \mathrm{c} 3 \%$ adsticos + total++residentes+em+Portugal +e+residentes+no+estrangeiro-2613-217313 (accessed 19 February 2021).

Pordata (2020a), "População estrangeira com estatuto legal de residente", available at: https://www. pordata.pt/Municipios/Popula $\% \mathrm{c} 3 \%$ a $7 \%$ c3\%a3o+estrangeira+com+estatuto+legal+de +residente+total+e+por+algumas+nacionalidades-101 (accessed 19 February 2021).

Printezis, I. and Grebitus, C. (2018), "Marketing channels for local food", Ecological Economics, Vol. 152, pp. 161-171.

Renting, H., Marsden, T. and Banks, J. (2003), "Understanding alternative food networks: exploring the role of short food supply chains in rural development", Environment and Planning A, Vol. 35, pp. 393-411.

Rezende, D. and Silva, M. (2014), "Eating-out and experiential consumption: a typology of experience providers", British Food Journal, Vol. 116 No. 1, pp. 91-103.

Seguí, A.E. (2011), "La Especialización del Sector Minorista de Alimentación en Dortmund (Alemania)", Investigaciones Geográficas, Vol. 56, pp. 97-112.

Singer, A. (2018), "Rescaling terroir through virtual identity work and impression management", Food, Culture and Society, Vol. 21 No. 5, pp. 698-715.

Truninger, M. (2014), "A cidade e o campo: memórias e práticas alimentares de um grupo de consumidores urbanos", in Baudin, G. and Vaz, D.M. (Eds), Transação territorial: novas relações cidade-campo, Húmus, Vila Nova de Famalicão, pp. 61-74.

Vignali, C., Vignali, M. and Ahmed, H. (2001), "The evolution of food retailing in Spain”, Journal of Food Products Marketing, Vol. 7 No. 3, pp. 63-81.

Vignali, G., Vignali-Ryding, D. and Sanchez, J. (2003), “The delicatessen and speciality food market in the North West”, British Food Journal, Vol. 105 No. 8, pp. 551-558.
Typology of urban speciality shops 
Watts, D., Little, J. and Ilbery, B. (2018), "I am pleased to shop somewhere that is fighting the supermarkets a little bit'. A cultural political economy of alternative food networks", Geoforum, Vol. 91, pp. 21-29.

Wilson, G.A. and Whitehead, I. (2012), "Local Rural Product as a relic? spatial strategy in globalised rural spaces: evidence from County Clare (Ireland)”, Journal of Rural Studies, Vol. 28, pp. 199-207.

\section{Corresponding author}

Alexandre Silva can be contacted at: alexandre.silva@ics.ulisboa.pt

For instructions on how to order reprints of this article, please visit our website: www.emeraldgrouppublishing.com/licensing/reprints.htm Or contact us for further details: permissions@emeraldinsight.com 